\title{
Front Matter: Volume 6473
}

, "Front Matter: Volume 6473," Proc. SPIE 6473, Gallium Nitride Materials and Devices II, 647301 (16 February 2007); doi: 10.1117/12.727171

Event: Integrated Optoelectronic Devices 2007, 2007, San Jose, California, United States 


\title{
PROCEEDINGS OF SPIE
}

\section{Gallium Nitride Materials and Devices II}

\author{
Hadis Morkoç \\ Cole W. Litton \\ Chairs/Editors
}

22-25 January 2007

San Jose, California, USA

Sponsored and Published by

SPIE-The International Society for Optical Engineering

Volume 6473

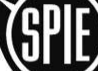

The International Society

for Optical Engineering

Proceedings of SPIE_-The International Society for Optical Engineering, 9780819465863, v. 6473

SPIE is an international technical society dedicated to advancing engineering and scientific applications of optical, photonic, imaging, electronic, and optoelectronic technologies. 
The papers included in this volume were part of the technical conference cited on the cover and title page. Papers were selected and subject to review by the editors and conference program committee. Some conference presentations may not be available for publication. The papers published in these proceedings reflect the work and thoughts of the authors and are published herein as submitted. The publisher is not responsible for the validity of the information or for any outcomes resulting from reliance thereon.

Please use the following format to cite material from this book:

Author(s), "Title of Paper," in Gallium Nitride Materials and Devices II, edited by Hadis Morkoç, Cole W. Litton, Proceedings of SPIE Vol. 6473 (SPIE, Bellingham, WA, 2007) Article CID Number.

ISSN 0277-786X

ISBN 9780819465863

Published by

SPIE-The International Society for Optical Engineering

P.O. Box 10, Bellingham, Washington 98227-0010 USA

Telephone 1 360/676-3290 (Pacific Time) · Fax 1 360/647-1445

http://www.spie.org

Copyright @ 2007, The Society of Photo-Optical Instrumentation Engineers

Copying of material in this book for internal or personal use, or for the internal or personal use of specific clients, beyond the fair use provisions granted by the U.S. Copyright Law is authorized by SPIE subject to payment of copying fees. The Transactional Reporting Service base fee for this volume is $\$ 18.00$ per article (or portion thereof), which should be paid directly to the Copyright Clearance Center (CCC), 222 Rosewood Drive, Danvers, MA 01923. Payment may also be made electronically through CCC Online at http://www.copyright.com. Other copying for republication, resale, advertising or promotion, or any form of systematic or multiple reproduction of any material in this book is prohibited except with permission in writing from the publisher. The CCC fee code is 0277 $786 \times / 07 / \$ 18.00$.

Printed in the United States of America. 


\section{Contents}

ix Conference Committees

xi Introduction

\section{GROWTH}

647302 New possibility of MOVPE-growth in GaN and InN: polarization in GaN and nitrogenincorporation in InN (Invited Paper) [6473-01]

T. Matsuoka, Tohoku Univ. (Japan) and CREST, Japan Science and Technology Agency (Japan)

647303 Two-step epitaxial lateral overgrowth of a-plane GaN by MOCVD [6473-02]

X. Ni, Ü. Özgür, H. Morkoç, A. A. Baski, Virginia Commonwealth Univ. (USA);

Z. Liliental-Weber, Lawrence Berkeley National Lab. (USA); H. O. Everitt, Duke Univ. (USA)

and U.S. Army Aviation \& Missile Research, Development and Engineering Ctr. (USA)

647304 Low dislocation density GaN grown by MOCVD with $\mathrm{SiN}_{\mathrm{x}}$ nano-network [6473-03]

J. Xie, Ü. Özgür, Y. Fu, X. Ni, H. Morkoç, Virginia Commonwealth Univ. (USA); C. K. Inoki,

T. S. Kuan, SUNY/Univ. at Albany (USA); J. V. Foreman, H. O. Everitt, Duke Univ. (USA) and

U.S. Army Aviation and Missile Research, Development and Engineering Ctr. (USA)

647305 Growth and polarity control of GaN and AIN on carbon-face SiC by metalorganic vapor phase epitaxy [6473-65]

Y. Fu, Q. Fan, S. Chevtchenko, Ü. Özgür, H. Morkoç, Virginia Commonwealth Univ. (USA);

Y. Ke, R. Devaty, W. J. Choyke, Univ. of Pittsburgh (USA); C. K. Inoki, T. S. Kuan, SUNY/Univ. at Albany (USA)

Pagination: Proceedings of SPIE follow an e-First publication model, with papers published first online and then in print and on CD-ROM. Papers are published as they are submitted and meet publication criteria. A unique, consistent, permanent citation identifier (CID) number is assigned to each article at the time of the first publication. Utilization of CIDs allows articles to be fully citable as soon they are published online, and connects the same identifier to all online, print, and electronic versions of the publication.

SPIE uses a six-digit CID article numbering system in which:

- The first four digits correspond to the SPIE volume number.

- The last two digits indicate publication order within the volume using a Base 36 numbering system employing both numerals and letters. These two-number sets start with 00, 01, 02, 03, 04, 05, 06, 07, 08, 09, 0A, OB ... 0Z, followed by 10-1Z, 20-2Z, etc.

The CID number appears on each page of the manuscript. The complete citation is used on the first page, and an abbreviated version on subsequent pages. 


\section{ELECTRICAL AND OPTICAL CHARACTERIZATION}

647306 Enhanced luminescence from $A l_{x} G_{a_{1-x}} N / A l_{y} G a_{1-y} N$ quantum wells grown by gas source molecular beam epitaxy with ammonia [6473-04]

S. A. Nikishin, B. A. Borisov, Texas Tech Univ. (USA); G. A. Garrett, W. L. Sarney, A. V. Sampath, H. Shen, M. Wraback, U.S. Army Research Lab. (USA); M. Holtz, Texas Tech Univ. (USA)

647307 Narrow-width photoluminescence spectra of InGaN quantum wells grown on GaN (0001) substrates with misorientation toward [1100] direction [6473-05] K. Tachibana, H. Nago, S. Nunove, Toshiba Corp. (Japan)

647308 AFM and CAFM studies of ELO GaN films [6473-06] V. Kasliwal, J. C. Moore, X. Ni, H. Morkoç, A. A. Baski, Virginia Commonwealth Univ. (USA)

647309 Magneto-transport properties of MOVPE-grown $\mathrm{Al}_{\mathbf{x}} \mathrm{Ga}_{1-\mathrm{x}} \mathrm{N} / \mathrm{AIN} / \mathrm{GaN}$ heterostructures with high-mobility two-dimensional electron gas [6473-07]

N. Biyikli, Virginia Commonwealth Univ. (USA); H. Cheng, Ç. Kurdak, Univ. of Michigan/Ann Arbor (USA); X. Ni, Y. FU, J. Xie, Virginia Commonwealth Univ. (USA); I. Vurgaftman, J. Meyer, Naval Research Lab. (USA); H. Morkoç, Virginia Commonwealth Univ. (USA); C. W. Litton, Air Force Research Lab. (USA)

64730A Investigation of current voltage characteristics of $n-G a N / i-A l_{x} \mathbf{G a}_{1-x} \mathbf{N} / \mathbf{n}-\mathbf{G a N}$ structures [6473-08]

X. Ni, J. Xie, Y. Fu, H. Morkoç, Virginia Commonwealth Univ. (USA); I. P. Steinke, Y. Liu, P. P. Ruden, Univ. of Minnesota (USA); K.-A. Son, B. Yang, Jet Propulsion Lab. (USA)

64730B Characterization of the carrier dynamics and interface-state charge fluctuations in quaternary AllnGaN multiple quantum well heterostructures [6473-57]

C.-C. Ke, C.-W. Hung, D.-C. Kuo, W.-J. Chen, H.-T. Shen, Y.-F. Wu, J.-C. Wang, T.-E. Nee, Chang Gung Univ. (Taiwan)

64730C Optical properties of Berthelot-type behaviors in quaternary AllnGaN multiple quantum well heterostructures [6473-58]

C.-W. Hung, C.-C. Ke, D.-C. Kuo, W.-J. Chen, H.-T. Shen, Y.-F. Wu, J.-C. Wang, T.-E. Nee, Chang Gung Univ. (Taiwan)

64730D Characterization of the carrier localization confinement for InGaN/GaN multiple quantum well heterostructures with hydrogen-flow treatments [6473-59]

T.-C. Kuo, W.-J. Chen, C.-C. Ke, C.-W. Hung, H.-T. Shen, J.-C. Wang, Y.-F. Wu, T.-E. Nee,

Chang Gung Univ. (Taiwan)

\section{SPECIAL TOPICS}

64730E Wide bandgap UV photodetectors: a short review of devices and applications (Invited Paper) [6473-09]

F. Omnès, CNRS Grenoble (France); E. Monroy, CEA Grenoble (France); E. Muñoz, Univ.

Politecnica de Madrid (Spain); J.-L. Reverchon, THALES Research and Technology (France) 
$64730 \mathrm{~F}$ Spontaneous polarizations, electrical properties, and phononic properties of GaN nanostructures and systems (Invited Paper) [6473-10]

T. Yamanaka, K. Sun, Y. Li, M. Dutta, M. A. Stroscio, Univ. of Illinois at Chicago (USA)

\section{POINT DEFECTS}

64730L Summary of deep level defect characteristics in GaN and AIGaN (Invited Paper) [6473-16] D. Johnstone, Semetrol (USA)

64730M Interplay of Ga vacancies, C impurities, and yellow luminescence in GaN [6473-17] F. Reurings, F. Tuomisto, Helsinki Univ. of Technology (Finland)

64730N Point defect reduction in GaN layers grown with the aid of $\mathrm{SiN}_{\mathrm{x}}$ nanonet by metalorganic chemical vapor deposition [6473-56]

S. A. Chevtchenko, J. Xie, Y. Fu, X. Ni, H. Morkoç, Virginia Commonwealth Univ. (USA);

C. W. Litton, Air Force Research Lab. (USA)

FETS I

647300 Quantum 1/f noise in GaN FETs, HFETs, MODFETs, and their oscillators' phase noise (Invited Paper) [6473-19]

P. H. Handel, A. M. Hall, Univ. of Missouri, St. Louis (USA); H. Morkoç, Virginia Commonwealth Univ. (USA)

64730P Accumulation of hot phonons in GaN and related structures (Invited Paper) [6473-20] A. Matulionis, I. Matulionienè, Semiconductor Physics Institute (Lithuania)

64730Q Subpicosecond time-resolved Raman studies of LO phonons in GaN (Invited Paper) [6473-21]

K. T. Tsen, Arizona State Univ. (USA); J. G. Kiang, Armed Forces Radiobiology Research Institute (USA) and Uniformed Services Univ. of the Health Sciences (USA); D. K. Ferry, Arizona State Univ. (USA); H. Morkoç, Virginia Commonwealth Univ. (USA)

64730R AIGaN/GaN MODFET regrown by rf-MBE on MOCVD templates [6473-62] J. Xie, H. Morkoç, Virginia Commonwealth Univ. (USA); L. Zhou, D. J. Smith, Arizona State Univ. (USA)

64730S AIGaN/GaN MOS transistors using crystalline $\mathrm{ZrO}_{2}$ as gate dielectric [6473-63] X. Gu, N. Izyumskaya, V. Avrutin, J. Xie, S. Chevtchenko, B. Xiao, H. Morkoç, Virginia Commonwealth Univ. (USA)

LEDS II

64730T InGaN/GaN nanocolumn LEDs emitting from blue to red (Invited Paper) [6473-22] K. Kishino, A. Kikuchi, H. Sekiguchi, S. Ishizawa, Sophia Univ. (Japan) and Japan Science and Technology Agency (Japan)

$64730 \mathrm{U}$ Nitride-based light-emitting diodes with p-AllnGaN surface layers prepared at various temperatures [6473-23]

C. W. Kuo, C. M. Chen, C. H. Kuo, G. C. Chi, National Central Univ. (Taiwan) 
64730V AIGaN-based deep ultraviolet light emitting diodes with reflection layer [6473-24]

M. Khizar, Y. M. Akhtar Raja, Univ. of North Carolina at Charlotte (USA)

LASERS I

64730X Recent achievements of AllnGaN based laser diodes in blue and green wavelength (Invited Paper) [6473-26]

T. Jang, O. H. Nam, K. H. Ha, S. N. Lee, J. K. Son, H. Y. Ryu, K. S. Kim, H. S. Paek, Y. J. Sung,

H. G. Kim, S. H. Chae, Y. H. Kim, Y. Park, Samsung Advanced Institute of Technology (South

Korea)

$64730 Y$ Long lifetime cW InGaN laser diodes by molecular beam epitaxy (Invited Paper) [6473-27] M. Kaver, W. S. Tan, S. E. Hooper, J. M. Barnes, J. Heffernan, Sharp Labs. of Europe (United Kingdom)

$64730 Z$ Degradation studies of InGaN/GaN heterostructure laser diodes using a Kelvin Force Microscope [6473-28]

A. Lochthofen, W. Mertin, G. Bacher, Univ. Duisburg-Essen (Germany); M. Furitsch,

G. Brüderl, B. Hahn, U. Strauss, V. Härle, OSRAM Opto Semiconductors (Germany)

\section{DEFECTS}

647311 The influence of alloy disorder and hydrostatic pressure on electrical and optical properties of In-rich InGaN compounds (Invited Paper) [6473-29]

T. Suski, G. Franssen, Institute of High Pressure Physics Unipress (Poland); A. Kamińska, Institute of Physics (Poland); A. Khachapuridze, H. Teisseyre, J. A. Plesiewicz, L. H. Dmowski, Institute of High Pressure Physics Unipress (Poland); H. LU, W. J. Schaff, Cornell Univ. (USA); M. Kurouchi, Y. Nanishi, Ritsumeikan Univ. (Japan)

647312 Defect studies in HVPE GaN by positron annihilation spectroscopy (Invited Paper) [6473-30] F. Tuomisto, Helsinki Univ. of Technology (Finland)

647313 Lanthanide impurity level location in GaN, AIN, and ZnO [6473-31]

P. Dorenbos, E. van der Kolk, Delft Univ. of Technology (Netherlands)

FETS II

647315 AIGaN/GaN field-plate FETs for microwave power applications (Invited Paper) [6473-33] H. Miyamoto, Y. Ando, Y. Okamoto, T. Nakayama, A. Wakejima, T. Inove, Y. Murase, K. Ota, K. Yamanoguchi, N. Kuroda, M. Tanomura, K. Matsunaga, R\&D Association for Future Electron Devices, NEC Corp. (Japan)

647316 Insulator engineering in GaN-based MIS HFETs (Invited Paper) [6473-34] N. Maeda, M. Hiroki, N. Watanabe, Y. Oda, H. Yokoyama, NTT Corp. (Japan); T. Yagi, NTT Advanced Technology Corp. (Japan); T. Makimoto, T. Enoki, T. Kobayashi, NTT Corp. (Japan) 
647317 Thermal analysis of AIGaN/GaN HFETs using electro-thermal simulation and micro-Raman spectroscopy [6473-35]

T. Fujishima, Ritsumeikan Univ. (Japan); K. Inove, R\&D Association for Future Electron Devices (Japan); K. Kosaka, A. Hinoki, Ritsumeikan Univ. (Japan); T. Yamada, T. Tsuchiya, J. Kikawa, S. Kamiya, R\&D Association for Future Electron Devices (Japan); A. Suzuki, Ritsumeikan Univ. (Japan) and R\&D Association for Future Electron Devices (Japan); T. Araki, Y. Nanishi, Ritsumeikan Univ. (Japan)

647318 Epitaxial growth and characterization of AIGaN/GaN HEMT devices on SiC substrates for RF applications [6473-36]

A. K. Sood, Y. R. Puri, Magnolia Optical Technologies, Inc. (USA); F. W. Clarke, U.S. Army Space and Missile Defense Command (USA); J. Deng, J. C. M. Hwang, Lehigh Univ. (USA); S. K. Brierley, Raytheon RF Components (USA); M. A. Khan, Univ. of South Carolina (USA); A. Dabiran, P. Chow, SVT Associates, Inc. (USA); O. A. Laboutin, R. E. Welser, Kopin Corp. (USA)

\section{LASERS II}

64731D TM-mode lasing and anisotropic polarization properties of AIGaN multiple quantum well lasers in deep-ultraviolet spectral region (Invited Paper) [6473-41]

H. Kawanishi, M. Senuma, T. Nukui, Kohgakuin Univ. (Japan)

64731E Comparison of optical properties of InGaN/GaN/AIGaN laser structures grown by MOVPE and MBE [6473-42]

T. Swietlik, C. Skierbiszewski, Institute of High Pressure Physics, Unipress (Poland);

R. Czernecki, TopGaN Ltd. (Poland); G. Franssen, P. Wiśniewski, Institute of High Pressure Physics, Unipress (Poland); M. Leszczyński, I. Grzegory, Institute of High Pressure Physics, Unipress (Poland) and TopGaN Ltd. (Poland); P. Mensz, T. Suski, Institute of High Pressure Physics, Unipress (Poland); P. Perlin, Institute of High Pressure Physics, Unipress (Poland) and TopGaN Ltd. (Poland)

64731F Progress in etched facet technology for GaN and blue lasers [6473-43] A. Schremer, C. Stagarescu, J. Hwang, F. Khaja, Vainateya, A. Morrow, A. Behfar, BinOptics Corp. (USA)

$64731 \mathrm{G}$ High quality UV AIGaN/AIGaN distributed Bragg reflectors and microcavities [6473-44] O. Mitrofanov, S. Schmult, M. J. Manfra, T. Siegrist, N. G. Weimann, A. M. Sergent, Bell Labs./Alcatel-Lucent (USA); R. J. Molnar, MIT Lincoln Lab. (USA)

$64731 \mathrm{H}$ High reflectivity ultraviolet distributed Bragg reflector based on AIGaN/AIGaN multilayer [6473-66]

R. Shimada, J. Xie, H. Morkoç, Virginia Commonwealth Univ. (USA)

\section{EXTENDED DEFECTS}

$64731 \mathrm{~J}$ Structural characterization of III-nitrides using electron microscopy (Invited Paper) [6473-46]

D. J. Smith, L. Zhou, M. R. McCartney, Arizona State Univ. (USA) 
64731K Nanoheteroepitaxy of GaN on columnar SiC substrates by metalorganic chemical vapor deposition [6473-64]

Y. Fu, Ü. Özgür, Q. Fan, N. Biyikli, S. Chevtchenko, H. Morkoç, Virginia Commonwealth Univ. (USA); Y. Ke, R. Devaty, W. J. Choyke, Univ. of Pittsburgh (USA); C. K. Inoki, T. S. Kuan, SUNY/Univ. at Albany (USA)

FETS III

64731L Characterization of transient behavior of AIGaN/GaN HEMTs (Invited Paper) [6473-48]

T. Mizutani, Nagoya Univ. (Japan)

$64731 \mathrm{M}$ Charge trapping on defects in AIGaN/GaN field effect transistors (Invited Paper) [6473-49]

O. Mitrofanov, M. J. Manfra, Bell Labs./Alcatel-Lucent (USA)

$64731 \mathrm{~N}$ Analytical model, simulation, and parameter extraction of AIGaN/GaN HEMT for microwave circuit applications [6473-50]

H. F. Huq, The Univ. of Texas-Pan American (USA); S. K. Islam, The Univ. of Tennessee (USA)

$647310 \quad 1 / f$ noise in the dark current of GaN QWIPs [6473-51]

A. M. Hall, P. H. Handel, Univ. of Missouri, St. Louis (USA)

LEDS IV

64731P Light extraction analysis for GaN-based LEDs (Invited Paper) [6473-52]

T.-X. Lee, K.-F. Go, T.-Y. Chung, C.-C. Sun, National Central Univ. (Taiwan)

64731R Convergence of optical spectroscopic system for characterization of InGaN/GaN multiquantum well light-emitting diodes [6473-54]

J. Park, D. Lee, S. Hong, J. W. Kim, B. Kim, Samsung Electro-Mechanics Co., Ltd. (South Korea)

$64731 \mathrm{~S}$ Confocal scanning electroluminescence spectro-microscope for multidimensional lightemitting property analysis [6473-55]

S. Hong, G. Onushkin, J. S. Park, B. K. Kim, D.-Y. Lee, A. Fomin, K. Ko, J. W. Kim, Samsung Electro-Mechanics Co., Ltd. (South Korea)

Author Index 


\title{
Conference Committees
}

\author{
Symposium Chair
}

Yakov Sidorin, Photineer Technology Group (USA)

Symposium Cochair

Ali Adibi, Georgia Institute of Technology (USA)

Program Track Chair

James G. Grote, U.S. Air Force Research Laboratory (USA)

Conference Chairs

Hadis Morkoç, Virginia Commonwealth University (USA)

Cole W. Litton, U.S. Air Force Research Laboratory (USA)

Conference Cochair

James G. Grote, U.S. Air Force Research Laboratory (USA)

Program Committee

Alison A. Baski, Virginia Commonwealth University (USA)

Shigefusa F. Chichibu, University of Tsukuba (Japan)

Jen-Inn Chyi, National Central University (Taiwan)

Nicolas Grandjean, École Polytechnique Fédérale de Lausanne (Switzerland)

Izabella Grzegory, Institute of High Pressure Physics, Unipress (Poland) and TopGaN Ltd. (Poland)

Yong-Tae Moon, LG Electronics Inc. (South Korea)

Yasushi Nanishi, Ritsumeikan University (Japan)

Kitt Reinhardt, Air Force Office of Scientific Research (USA)

Donald J. Silversmith, Air Force Office of Scientific Research (USA)

Session Chairs

1 Growth

Alison A. Baski, Virginia Commonwealth University (USA)

2 Electrical and Optical Characterization

Charles C. Surya, The Hong Kong Polytechnic University (Hong Kong China) 
3 Special Topics

Jen-Inn Chyi, National Central University (Taiwan)

4 LEDs I

Hadis Morkoç, Virginia Commonwealth University (USA)

5 Point Defects

Cole W. Litton, U.S. Air Force Research Laboratory (USA)

6 FETS I

Hadis Morkoç, Virginia Commonwealth University (USA)

T. Mizutani, Consultant (USA)

7 LEDs II

Chuong A. Tran, SemiLEDs Corporation (USA)

8 Lasers I

Piotr Perlin, Institute of High Pressure Physics, Unipress (Poland) and TopGaN Ltd. (Poland)

9 Defects

Franck Omnès, CNRS Grenoble, Institut Néel (France)

10 FETs II

Yasushi Nanishi, Ritsumeikan University (Japan)

11 LEDs III

Katsumi Kishino, Sophia University (Japan) and CREST, Japan Science and Technology Agency (Japan)

12 Lasers $\|$

Joong-Kon Son, Samsung Advanced Institute of Technology (South Korea)

13 Extended Defects

Hadis Morkoç, Virginia Commonwealth University (USA)

14 FETS III

Arvydas Matulionis, Semiconductor Physics Institute (Lithuania)

15 LEDS IV

Tadeusz Suski, Institute of Physics (Poland) 


\section{Introduction}

The conference on Gallium Nitride Materials and Devices, christened last year as a tribute to cap the long and productive career of Dr. G. L. Witt, continued very successfully in 2007.

As mentioned in the introduction for the $2006 \mathrm{GaN}$ Materials and Devices proceedings, attainment of p-type GaN in the late 1980s broke open the logjam that had prevented researchers from demonstrating the many attractive attributes of GaN for decades. In fewer than a couple of decades since then, even with materials nowhere near the perfection that would be required for other materials, both optical and electronic devices with record-breaking or previously unavailable performance/property have been obtained. Today, the GaN-based light emitters adorn automobiles, traffic lights, moving signs, outdoor displays, handheld electronics, and background lighting in many consumer electronics, including flat-panel televisions. Soon, the more extensive applications of GaN light emitters in televisions will be seen in the marketplace. All-LED outdoor white lighting applications are already in full swing, with high-brightness large-area wafer-bonded LEDs producing optical power levels in excess of $200 \mathrm{~mW}$. Highend LEDs exhibit efficacies well above $100 \mathrm{l} / \mathrm{W}$ and are being achieved by increasing numbers of LED manufacturers. Indoor general lighting applications are very near with acceptable color rendering index, not to mention the color temperature.

It is really an exciting time for GaN-based LEDs, in that applications to general illumination seem to be around the corner with tremendous advances in light extraction methods with efficiencies approaching $80 \%$, which is remarkable. GaN-based LEDs truly represent the hottest device today, and will soon save many terawatts of power per year from being wasted. This could not come at a better time, when greenhouse emission gasses and the carbon footprint that we leave on Earth are increasingly becoming front page news in newspapers and other mass communication media across the globe. GaN-based lasers also are making their presence known with the introduction of PlayStation III by Sony late in 2006. UV detectors, particularly those in the solar blind region of the spectrum, with performance comparable to venerable photomultiplier tubes but at a fraction of the size and power requirement, have been accomplished. In the radio frequency power arena, one GaN chip is now able to produce CW power levels above $400 \mathrm{~W}$ at $2 \mathrm{GHz}$ and some $10 \mathrm{~W}$ in the millimeter-wave region for applications in the wireless and agile radar.

The SPIE conference on GaN Materials and Devices served to disseminate the latest results and provide an opportunity for researchers from around the world to engage in discussions to advance this exciting field even further. Many worldrenowned invited speakers from Asia, Europe, and the USA set the stage with 
discussions related to extended and point defects; characterization of GaN and related materials and efforts/methods to reduce defects; fundamental processes that are taking place in GaN in the context of defects, carrier and phonon dynamics, and their influence on transport and noise; very high-power FETs with hundreds of watts of power from single chips, for example base station power levels of $370 \mathrm{~W}$ and pulsed power of $750 \mathrm{~W}$ (this power levels changes upward daily); much improved lasers with over 10,000 hr projected operating lifetimes at $50 \mathrm{~mW}$ power, UV lasers and emission modes; detectors; and finally not just bright but HOT LEDs which continue to take the world by storm not only for displays and background lighting endemic in many consumer electronics, but also outdoor lighting, while inching ever closer to indoor illumination (dubbed with a misnomer of solid state lighting). Very high-quality contributed papers augmented and enhanced the truly exceptional image set forth by the invited speakers. Most importantly, the meeting served the purpose of getting experts in the field together for friendship and informal discussions of issues relevant to GaN and related materials and devices.

Hadis Morkoç Cole W. Litton 